\title{
IDENTIFICATION OF MULTIDRUG RESISTANT ESCHERICHIA COLI FROM THE DRINKERS OF BROILER CHICKEN POULTRY STATIONS LOCATED ACROSS THE VIRUDHUNAGAR DISTRICT, TAMIL NADU, INDIA
}

\author{
BALAJI SUNDARAMAHALINGAM ${ }^{1}$, CHANDAN SANTHILAL ${ }^{2}$, NARAYANAN MARIMUTHU ${ }^{3}$
}

${ }^{1}$ Department of Zoology, Ayya Nadar Janaki Ammal College (Autonomous), Sivakasi, Tamil Nadu, India. ${ }^{2}$ Nano Cera Enviro India Pvt. Ltd., Sivakasi, Tamil Nadu, India. ${ }^{3}$ Department of Biotechnology, Ayya Nadar Janaki Ammal College (Autonomous), Sivakasi, Tamil Nadu, India. Email: indianbala14@gmail.com

Received: 05 May 2021; Revised and Accepted: 12 June 2021

\section{ABSTRACT}

Objectives: The present investigation aimed to identify the multidrug resistance Escherichia coli bacteria in drinkers of poultry stations located across the Virudhunagar district, Tamil Nadu, India. Because water is the most important part of digestion in the growing chicks of poultry stations, but the quality of water supplied is often negotiated and the water drinkers in poultry farms has becoming the heavenly ground for antibiotic resistance (ABR) generation.

Methods: Hence in the present investigation water samples from the drinkers of five poultry stations were collected and analyzed for E. coli resistance bacteria using the disk diffusion method of Bauer-Kirby technique.

Results: Screening for ABR against the disc of penicillin, ampicillin, chloramphenicol, streptomycin, kanamycin, and cephalosporin were performed. Among the water samples collected from drinkers of five sampling sites, three sampling sites were found to show resistance bacteria against the different antibacterial disc used.

Conclusion: To overcome the development of ABR bacterial strains from poultry stations point of use disinfectant techniques rather than using chlorine and other chemical disinfectants can be developed to alleviate this problem.

Keywords: Multidrug resistance bacteria, Poultry farms, Antibiotic resistance and antibacterial disc.

(c) 2021 The Authors. Published by Innovare Academic Sciences Pvt Ltd. This is an open access article under the CC BY license (http://creativecommons.org/ licenses/by/4.0/) DOI: http://dx.doi.org/10.22159/ajpcr.2021v14i8.41981. Journal homepage: https://innovareacademics.in/journals/index.php/ajpcr

\section{INTRODUCTION}

According to the global food industry prediction it is came to know that the poultry products are at the highest level of production and consumption by the human beings and this scenario will found to increase in years to come. This increase level in demand already directed towards intense poultry farming methods globally and results in the forming many opportunistic bacteria. This simultaneously increased the use of antibiotics as an integral part of the poultry to treat and prevent infectious diseases and also as growth promoters in its early stages of chicks. This in turn has led to the problem in developing antibiotic resistance (ABR) microbes during the recent years. As India is one of the top global producers as well as the top consumer of fish, poultry and dairy products, it does not have adequate management system to control these problems arising from this scenario [1].

When compared with other animal husbandry products the growth of poultry sector was found to be $5 \%$ which will be higher when correlated with growth rate of $3 \%$ for pig meat and $1.5 \%$ for bovine meat. For the past three decades the meat production from chicken industry has also increased from $15 \%$ to $30 \%$ [2]. Usually in the poultry farms, antibiotics are applied to the chicks in avoiding the economic loss to the farmers which may arising from the intestinal infections such as colibacillosis, necrotic enteritis, and other diseases generally caused by Salmonella, Escherichia coli, or Clostridium spp. [3].

Resistance in bacterial usually develops naturally over time due to the unparalleled use of antibiotics and results in the increase of antimicrobial resistant organisms [4]. Many forces play a role in the spread of antimicrobial resistant bacteria include the presence of carrier animal moving between animal herds and through vector action [5]. Here in the poultry farms these ABR strains of Streptococcus, Salmonella, and E. coli can be transmitted to the bird communities though the drinking water from water contamination by feces and secretions of sick birds, or by the utilization of water already contaminated by pathogenic organisms respectively [6].

Dhanarani et al. [7] identified the presence of ABR bacteria from one hundred twenty poultry litter samples and studied the mode of transmission in poultry farms. Hence the present study is undertaken to identify the presence of multidrug resistance $E$. coli isolates in the drinkers of poultry stations.

\section{METHODS}

Sampling

Water sample collection was done from five poultry farms during 2018 to 2019 from different parts of Virudhunagar District, Tamil Nadu. These farms were distributed within five different Taluks of Virudunagar District, Tamil Nadu. The number of birds in farms ranged from 4000 to 5000 . Through the examination it was found that all the farms were using antibiotics for different infections. Water samples from the drinkers kept inside the station and also from the source where the water to the poultry stations were also collected to analyze development of ABR E. coli.

Antibiotic susceptibility test

The antibiotic susceptibility pattern of all the isolated E. coli bacteria from each farm as well as from source water samples were determined using the disk diffusion method of Bauer-Kirby technique [8]. Pure cultures of E. coli isolated from the drinkers water samples were collected and grown in nutrient broth separately. Then the pure 
cultures were swabbed off from the plates using sterile swabs and used for the antibiotic susceptibility test. Discs of different antibiotics were placed aseptically on the plates poured with E. coli isolated from the drinkers as well as from the source water (three discs on one plate) and incubated at $37^{\circ} \mathrm{C}$ for $24 \mathrm{~h}$ for different antibiotics in triplicate.

\section{RESULTS AND DISCUSSION}

Before carrying out the present work, we performed an oral investigation about the life cycle, demographic setups in a farm and diseases affecting the broilers chickens of different poultry farms. From our investigation we have observed that during the each batch of 2500 individuals of chicks in a farm can be able to give rise to only 2200-2250 individuals finally and the remaining chicks will be died of different environmental factors and diseases. However, the chicks were periodically treated with vaccines and antibiotics but the mortality continues to exits in all farms. This mortality may due to development of pathogenesis of ABR $E$. coli due to poor sanitation and overcrowding of chicks in the farms. Hence the present study aimed to identify the resistance developed by the bacteria in the water samples of drinkers kept in the poultry farms for the chicks.

In the antibacterial disc diffusion assay it was observed that the maximum zone of inhibition or sensitiveness was observed in Gentamicin disc ( 6 and $4 \mathrm{~mm}$ ) against the water samples collected from the sample sites in S4 and S2. It was followed by the Vancomycin disc ( 4 and $3 \mathrm{~mm}$ ) against the samples collected from S2 and S4 sites. The other sensitiveness or inhibition were observed in Tetracyclin and Sulfonamides disc plates against the collected samples from S2 and S4 (Table 1 and Fig. 1). Similar kinds of results were also supported by Bhusan [1] who reported that the $E$. coli isolates from poultry farm soil had low resistance to the antibiotic discs such as Amikacin and Gentamicin.

From the results it was inferred that the water samples collected from 3 poultry farms S1, S3 and S5 found to contain $100 \%$ resistant E. coli isolates against the seven antibiotic discs used (Table 2).

Table 1: Diameter of zone of inhibition by different antibiotic disc against the Escherichia coli isolates collected from drinkers of different poultry farms

\begin{tabular}{llllll}
\hline $\begin{array}{l}\text { Name of the } \\
\text { antibiotic disc }\end{array}$ & \multicolumn{5}{l}{$\begin{array}{l}\text { Mean diameter of the zone of inhibition in } \\
\text { different sampling sites (in mm) }\end{array}$} \\
\cline { 2 - 6 } & S1 & S2 & S3 & S4 & S5 \\
\hline Penicillin & 0 & 0 & 0 & 0 & 0 \\
Ampicillin & 0 & 0 & 0 & 0 & 0 \\
Tetracycline & 0 & 2 & 0 & 3 & 0 \\
Chloramphenicol & 0 & 0 & 0 & 0 & 0 \\
Vancomycin & 0 & 4 & 0 & 3 & 0 \\
Streptomycin & 0 & 0 & 0 & 0 & 0 \\
Kanamycin & 0 & 0 & 0 & 0 & 0 \\
Gentamycin & 0 & 5 & 0 & 6 & 0 \\
Sulfonamides & 0 & 0 & 0 & 3 & 0 \\
Cephalosporins & 0 & 0 & 0 & 0 & 0 \\
\hline
\end{tabular}

S1 to S5 - sampling sites

Table 2: Percentage of resistance developed by the bacteria isolated from different water samples collected from drinkers of different poultry farms

\begin{tabular}{lll}
\hline $\begin{array}{l}\text { Sampling } \\
\text { sites }\end{array}$ & $\begin{array}{l}\text { Number of antibiotic } \\
\text { disc used }\end{array}$ & $\begin{array}{l}\text { Percentage of resistance } \\
\text { developed by the Escherichia } \\
\text { coli against the disc }\end{array}$ \\
\hline S1 & 10 & 100 \\
S2 & 10 & 70 \\
S3 & 10 & 100 \\
S4 & 10 & 60 \\
S5 & 10 & 100 \\
\hline
\end{tabular}

Similar kinds of results were also supported by Bhushan [1] who reported the presence of $\mathrm{ABR}$ in $E$. coli in both litter and nearby agricultural soil of poultry farms samples isolated from Haryana, Uttar Pradesh, Rajasthan, and Punjab. Out of 187 samples they have screened $67 \mathrm{E}$. coli isolates which are resistant against penicillin, fluoroquinolone, ceftriaxone, cephalosporin and cefuroxime antibiotic discs.

In a recent study published in the Environmental Health Perspectives, the antibiotic used in 18 broiler and layer poultry farms in Punjab was leading to the emergence of ABR bacteria. The report also shows that there is an elevated occurrence of multidrug resistant $E$. coli strains from cloacal swab samples of birds in broiler farms. They said that emergence of multidrug resistance $E$. coli was more common among the broiler farms when compared with the layer farms [9]. According to Chaudhary and Piya [10], multidrug resistance Staphylococcus aureus which are isolated from the clinical specimens of Nepal found to have susceptibility to glycopeptides antibiotics such as vancomycin antibiotic disc [10]. Mwambete and Stephen [11] also observed the high rates of ABR bacterial strains from the chicken droppings in Dar Es Salaam farms located in Tanzania.

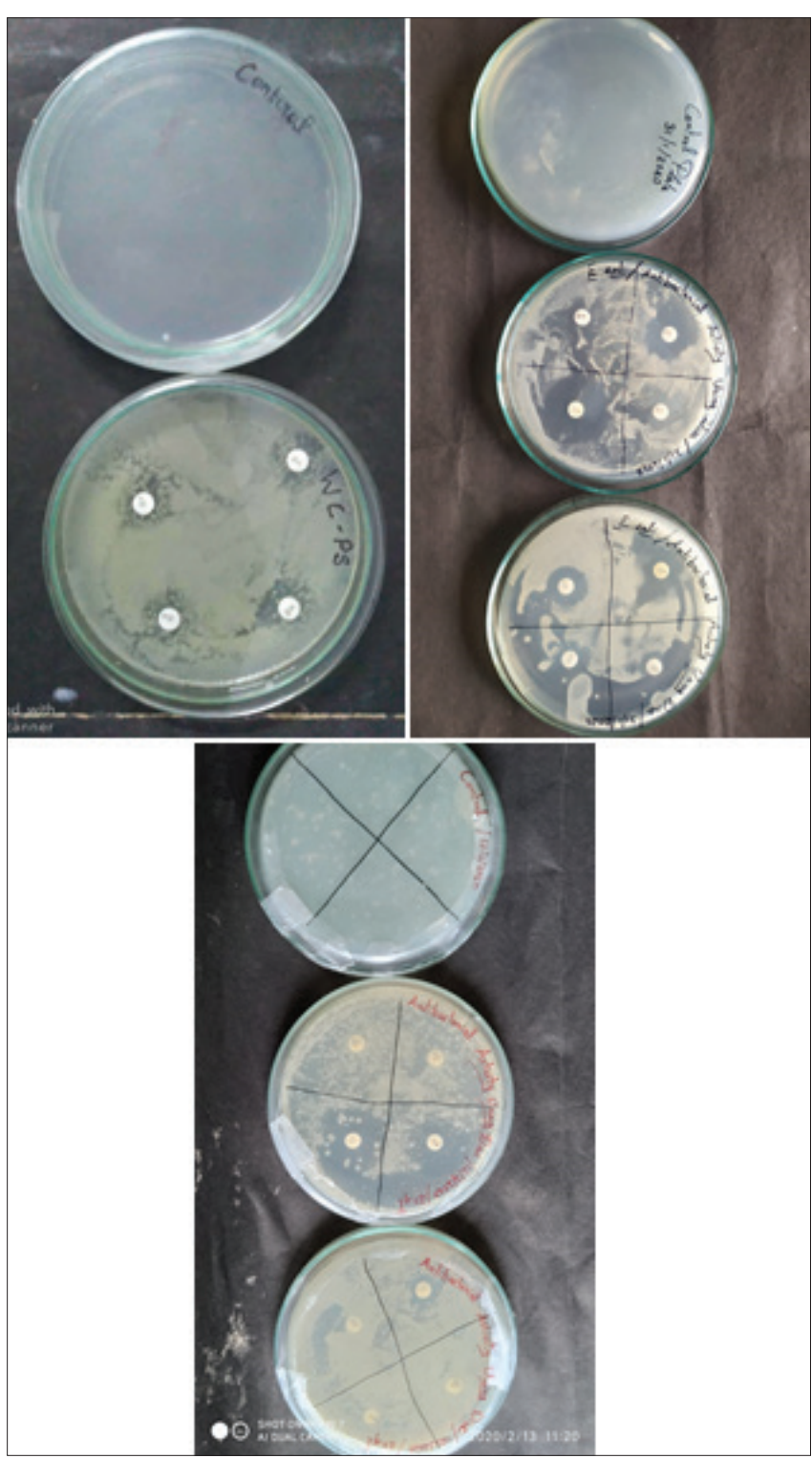

Fig. 1: Antibiotic resistance and susceptibility of Escherichia coli against the different antibiotic disc 


\section{CONCLUSION}

Therefore we affirmed to say that this ABR development in E. coli can enter human food chain and cause drastic effects. Hence an alternate protective mechanism to nullify the development of ABR bacteria in the drinkers of poultry farms can be developed in future.

\section{ACKNOWLEDGEMENTS}

The authors are thankful to the Management of Ayya Nadar Janaki Ammal College (Autonomous), Sivakasi for providing necessary lab facilities to carry out the work.

\section{AUTHOR'S CONTRIBUTION}

BS: Concept and design of the study and drafting the final version of the manuscript. CS: Analysis and interpretation of data. NM: Collection of field samples.

\section{CONFLICTS OF INTERESTS}

The authors have no conflicts of interest in publishing this manuscript.

\section{FUNDING}

The present investigation has been carried out with the self-funding from the authors.

\section{REFERENCES}

1. Bauer AW, Kirby WM, Sherris JC, Turck M. Antibiotic susceptibility testing by a standardized single disk method. Am J Clin Pathol 1966;45:493-6.
2. Bhushan C, Khurana A, Sinha R Nagaraju M. Antibiotic Resistance in Poultry Environment: Spread of Resistance from Poultry Farm to Agricultural Field. New Delhi: Centre for Science and Environment; 2017

3. Brower CH, Mandal S, Hayer S, Sran M, Zehra A, Patel SJ. The prevalence of extended-spectrum beta-lactamase-producing multidrug resistant Escherichia coli in poultry chickens and variation according to farming practices in Punjab, India. Environ Health Perspect 2017; 125:077015

4. Dargatz DA, Fedorka-Cray PJ, Ladely SR, Ferris KE. Survey of Salmonella serotypes shed in feces of beef cows and their antimicrobial susceptibility patterns. J Food Prot 2000;63:1648-53

5. Food and Agriculture Organization. World Agriculture: Towards 2030/2050 Interim Report. Rome: Food and Agriculture Organization; 2006

6. Gama MS. Água, Que Cura, Que Nutre, Que Mata. Aves and Ovos; 1995. p. 30-3.

7. Levy S. Reduced antibiotic use in livestock: How Denmark tackled resistance. Environ Health Perspect 2014;122:160-5.

8. Dhanarani TS, Shankar C, Park J, Dexilin M, Kumar R, Thamaraiselvi KR. Study on acquisition of bacterial antibiotic resistance determinants in poultry litter. Poult Sci 2009;88:1381-7.

9. United States Department of Agriculture. Economics of Antibiotic Use in U.S. livestock Production. United States: United States Department of Agriculture; 2015. http://www.ers.usda.gov/media/1950577/err 200.pdf.

10. Chaudhary N, Piya R. Macrolide-lincosamide streptogramin b resistance among Staphylococcus aureus in Chitwan Medical College Teaching hospital, Nepal. Asian J Pharm Clin Res 2021;14:61-5.

11. Mwambete KD, Stephen WS. Antimicrobial resistance profiles of bacteria isolated from chicken Droppings in Dar Es Salaam. Int J Pharm Pharm Sci 2015;7:268-27. 